\section{Identification of Genes Regulated by Low Temperature in Pachysandra terminalis Sieb. et Zucc Using cDNA Differential Display}

\author{
Suping Zhou, Roger J. Sauve, ${ }^{1}$ and Abdulah Abdulah \\ Tennessee State University, 3500 J.A. Merritt Boulevard, Nashville, TN 37209-1561
}

Additional index words. japanese spurge, temperature stress, cold-inducible genes, cold and heat shock

\begin{abstract}
Complementary Deoxyribonucleic Acid (cDNA) differential display and reverse Northern dot blot were used to identify genes in Pachysandra terminalis Sieb. \& Zucc., a cold-tolerant plant, that are regulated by low temperatures. Rooted cuttings were obtained from stock plants that had been maintained in a greenhouse at $24^{\circ} \mathrm{C}$. These cuttings were subjected to the following cold treatments: 2 weeks at $12{ }^{\circ} \mathrm{C}, 48$ hours at $4{ }^{\circ} \mathrm{C}, 48$ hours at $0{ }^{\circ} \mathrm{C}$, and 4 hours at $-1{ }^{\circ} \mathrm{C}$. Following leaf tissue analysis of treated and control plants, some stress-related genes and many novel genes were identified. Northern blot hybridization demonstrated that all novel genes were regulated by the cold treatments.
\end{abstract}

Chilling and freezing temperatures adversely affect productivity and quality of crops in the temperate regions of the world. Low temperatures induce a number of changes in the metabolism of plant cells and in the expression level of a number of genes referred to as cold-inducible genes or cold responsive genes (Nishida and Murata, 1996; Zhou et al., 2005). Cold inducible genes have been cloned from a number of plants species as well as from other organisms. These genes are classified as $d h n$, lea, rab-related genes (dehydrin, late embryogenesis abundant, responsive to abscisic acid related genes). Some transcription regulation factors and mechanisms that control the expression of cold inducible genes have also been identified (Kitasiba et al., 2004; Gilmour et al., 2000; Owens et al., 2002; Zhu, 2001).

It is widely accepted that change in gene expression is an integral part of the cellular response to thermal stress in plants. Thermal stress triggers a complex series of gene expression and biochemical adaptive responses. Regulation of gene expression is often the early response for generating cellular changes (Polisensky and Braam, 1996). The ability of plants to tolerate and adapt to low temperature varies among species and cultivars (Tsonev et al., 2003). To develop protocols for improving cold tolerance in plants, an understanding of the mechanisms responsible for adaptation is essential.

Parchysandra terminalis is a cold tolerant plant that can survive where the winter temperature is as low as -26.1 to $-23.3^{\circ} \mathrm{C}$ (USDA zones 5 to 9 ) without entering dormancy. To

\footnotetext{
Received for publication 1 Aug. 2005. Accepted for publication 1 Sept. 2005. This project was supported by two Higher Education Capacity Building Program grants (projects \#2004-38814-15048 and \#2002-38814-12598). The authors thank Sarabjit Bhatti and FurChi Chen for critical review of the manuscript.

${ }^{1}$ To whom reprint requests should be addressed; e-mail rsauve@tnstate.edu.
}

cope with cold stress, P. terminalis has evolved mechanisms for survival (Suping et al., 2005). Initial observations of cold treated plants indicated that leaf-appearance was not affected by treatments ranging from -1 to $-2{ }^{\circ} \mathrm{C}$ for 4 to 6 $\mathrm{h}$ (unpublished data). But, after $24 \mathrm{~h}$ at $-2{ }^{\circ} \mathrm{C}$ leaves were dehydrated and recovered quickly once returned to a greenhouse at $24^{\circ} \mathrm{C}$. The objective of this research was to identify genes in P. terminalis that have high expression levels when plants are subjected to cold stress.

\section{Material and Methods}

Plant preparation and temperature treatment for $\mathrm{DNA}$ differential display experiment. Rooted cuttings of $P$. terminalis with six fully-expanded leaves were planted in 4-L containers and grown in a glasshouse for $30 \mathrm{~d}$ under natural daylight at 24 to $26^{\circ} \mathrm{C}$. Before the initiation of low temperature treatments, plants were placed in a growth chamber at $24{ }^{\circ} \mathrm{C}\left(16-\mathrm{h}\right.$ photoperiod at $40 \mu \mathrm{mol} \cdot \mathrm{m}^{-2} \cdot \mathrm{s}^{-1}$ light intensity at the pot level) for 2 weeks to induce new leaves. To initiate cold temperature acclimation, these plants were moved to an incubator at $12{ }^{\circ} \mathrm{C}$ for 2 weeks and were exposed for $48 \mathrm{~h}$ at $4{ }^{\circ} \mathrm{C}$, for $48 \mathrm{~h}$ at $0^{\circ} \mathrm{C}$, and for $4 \mathrm{~h}$ at $-1{ }^{\circ} \mathrm{C}$.

$R N A$ extraction, differential display and cloning of target genes. Following each treatment, all leaves formed during the 2-weekincubation at $24{ }^{\circ} \mathrm{C}$ were removed and quickly frozen in liquid nitrogen and stored at -70 ${ }^{\circ} \mathrm{C}$ until processed. The total RNA from each leaf sample was extracted using Genhunters' RNApure kit (TN). The genomic DNA was digested (Genhunters' DNA messenger clean kit) and the target RNA samples were labeled with ${ }^{32} \mathrm{P}-\mathrm{dCTP}$ (Amersham Biosciences) by first-strand cDNA synthesis. Differently expressed cDNA fragments were amplified using the three-one-base-anchored oligo-dT primers and all the 80 arbitrary 13 -mer primers provided with the RNAimage kit (Genehunt- ers). All cDNA fragments were separated on a $5.5 \%$ nondenaturing acrylamide gel and signals were detected by exposing the gel overnight on $\mathrm{X}$-ray film at $-70^{\circ} \mathrm{C}$. cDNA bands displaying increased or decreased intensity were considered to contain cold inducible genes. These genes were recollected from the acrylamide gels and reamplified with the same primers previously used and cloned on PCR-Trap cloning vector (Genehunter's). Positive clones were selected on LB medium supplemented with tetracycline $\left(20 \mathrm{mg} \cdot \mathrm{L}^{-1}\right)$.

Selection of positive clones with the targeted genes. Colony hybridization was carried out to select bacterial colonies carrying gene inserts and to eliminate false positive clones that resulted from self-ligation with the vector. To perform this procedure, five independent Escherichia coli colonies were collected from each gene clone and transferred to LB medium. Colonies were then lifted onto nitrocellulose membranes (PerkinElmer, Mass.) and incubated at $37^{\circ} \mathrm{C}$ for $10 \mathrm{~h}$. All colonies were lysed and denatured twice for 3 min each time in $0.5 \mathrm{~N} \mathrm{NaOH} / 1.5 \mathrm{M} \mathrm{NaCl}$ buffer. The DNA was neutralized twice for 3 min each time in $0.5 \mathrm{M}$ Tris- $\mathrm{HCl}(\mathrm{pH} 7.0) 1.5$ $\mathrm{M} \mathrm{NaCl}$ buffer and fixed onto membranes by autoclaving at $100{ }^{\circ} \mathrm{C}$ for $1 \mathrm{~min}$ and baked at $60{ }^{\circ} \mathrm{C}$ for $4 \mathrm{~h}$. Membranes were hybridized using probes that were synthesized from a pool of RNAs obtained from leaf tissues that were incubated at $-1,0$, and $4{ }^{\circ} \mathrm{C}$ and labeled with ${ }^{32} \mathrm{P}-\mathrm{dCTP}$ using a reverse cDNA labeling kit (Genehunters). The conditions for membrane hybridization were overnight prehybridization at $42{ }^{\circ} \mathrm{C}$ and overnight hybridization at $42{ }^{\circ} \mathrm{C}$ followed by two 20 -min washes in $1 \times$ SSC at $24{ }^{\circ} \mathrm{C}$, in $0.25 \times \mathrm{SSC}$, and in $0.1 \% \mathrm{SDS}$ at $50{ }^{\circ} \mathrm{C}$. Both the prehybridization and hybridization buffers contained $50 \%$ formamide, $0.1 \%$ SDS, $5 \times$ Denhardt, $5 \times$ SSPE, and 100 $\mathrm{mg} \cdot \mathrm{L}^{-1}$ herring sperm DNA (Sigma). After hybridization, signals were detected on X-Ray film. One positive clone was selected for each transformation event.

Reverse northern blot was carried out to select cold inducible gene candidates. cDNA inserts from selected clones were PCR amplified and transferred onto $\mathrm{N}^{+}$nylon membrane using a 96-well Bio-Dot SF apparatus (Biorad, CA). The DNA was fixed to the membrane by baking at $80^{\circ} \mathrm{C}$ for $2 \mathrm{~h}$. Membrane hybridization and signal detection were also performed using the above procedure. For further studies, genes that were induced by cold treatments were selected by comparing the intensity of radioactive signals between the cold treated and untreated DNA on X-ray film.

$R N A$ northern blot hybridization. cDNA fragments of genes novel to $P$ terminalis were selected to synthesize probes for RNANorthern hybridization. Total RNA was extracted from leaves of plants that had been incubated at 4 ${ }^{\circ} \mathrm{C}$, for $8 \mathrm{~h}$ and for $16 \mathrm{~h}$, and at $-1{ }^{\circ} \mathrm{C}$ for $4 \mathrm{~h}$. For testing the regulation of selected genes due to temperature fluctuations, plants that were incubated at $4{ }^{\circ} \mathrm{C}$ for $8 \mathrm{~h}$ were subjected to heat shock at $45^{\circ} \mathrm{C}$ for $30 \mathrm{~min}$. RNA samples were separated on agarose-formaldehyde gels (30 $\mu \mathrm{g} /$ lane) by electrophoresis and transferred to 
nitrocellulose membranes. Membranes were hybridized overnightat $50^{\circ} \mathrm{C}$ with DNA probes that were synthesized from selected clones as the template (Genhunters Hot-Prime DNA labeling kit) and were labeled with ${ }^{32} \mathrm{P}$-dATP using the same pre- and hybridization procedures used for colony hybridization.

Sequence analysis and database searching. Plasmids of selected clones were amplified in E. coli cultured in LB liquid medium without antibiotics. Plasmids were isolated using a kit
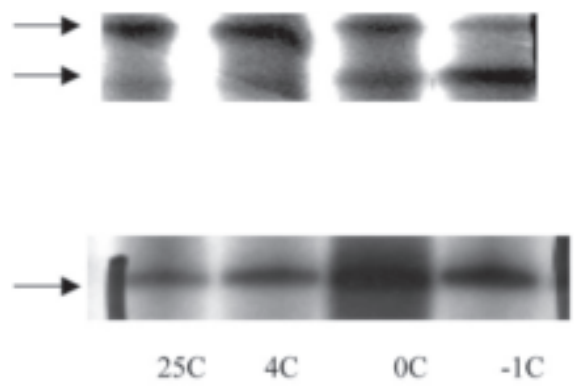

Fig. 1. Acrylamide gel showing the cDNA differential display of Pachysandra terminalis. Arrows indicate bands that were different following the cold treatments of plants.
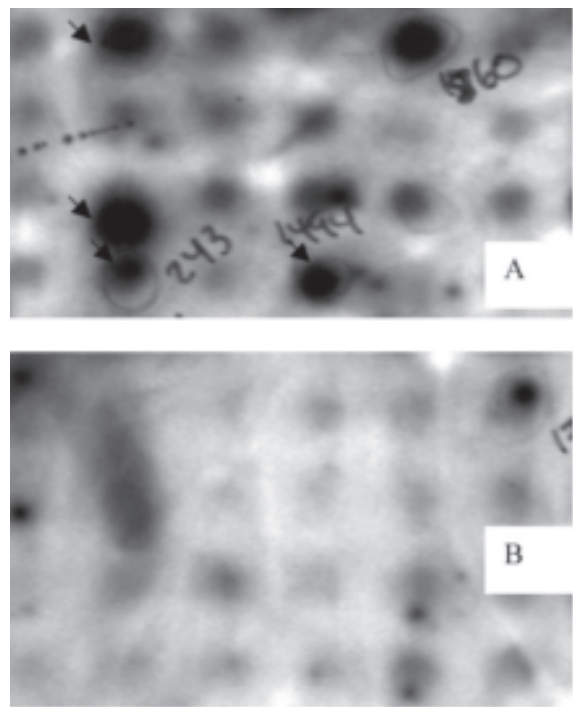

Fig. 2. Selection of cold inducible gene clones from Pachysandra terminalis using reverse northern blot (A). This membrane was hybridized with cDNA probes synthesized from a pool of mRNA from plants that were subjected to 0,4 , and -1 ${ }^{\circ} \mathrm{C}$ and $(\mathbf{B})$ from control plants $\left(25^{\circ} \mathrm{C}\right)$. Arrows point to gene spots that were induced by the cold treatments. obtained from Qiagen and sequenced with a DNA sequencer (LI-IR2 model 4200L; LICOR, Lincoln, Neb.). DNA sequences were compared with those reported in the NCBI database (NR andEST) and identified based on their homology with reported genes. Genes that shared $>85 \%$ of their sequences with reported genes were considered to be homologous and those that shared short fragments (20 to $50 \mathrm{bp}$ ) were considered novel to $P$. terminalis.

\section{Results and Discussion}

Screening genes regulated by low temperatures. cDNAdifferential display was used to identify differences in gene expression. Gene transcripts from plants treated with temperatures ranging from 4 to $-1{ }^{\circ} \mathrm{C}$ were separated in acrylamide gel. From images of the acrylamide gel, gene fragments displaying lower signal intensity (Fig. 1, band 1) or stronger signals following cold treatments (Fig. 1, Band 2) were identified. However, most bands displayed similar intensities following most cold treatments and $25^{\circ} \mathrm{C}$ control. The cDNA bands that showed variations following low temperature treatments were considered cold-inducible genes and were cloned onto PCR-trap vectors and selected on LB medium with tetracycline.

To eliminate false positives from self-ligation, all clones were hybridized and subjected to reverse northern blothybridization using cDNA probes that were synthesized from a pools RNA extracted from cold treated plants. Clones with positive or increased signals intensities (Fig. 2) were sequenced and compared with those reported in the NCBI database. Some sequenced clones were highly homologous with stress inducible genes reported in the database while most were not (Table 1). Unreported sequences were considered to be novel.

Selection of genes regulated by temperature fluctuations. Northern hybridization results (Fig. 3) showed that all selected genes with the exception of genes labeled JP3 and JP5 were up-regulated by the cold treatments at 4 ${ }^{\circ} \mathrm{C}$ for 8 and $16 \mathrm{~h}$ and $-1{ }^{\circ} \mathrm{C}$ for $4 \mathrm{~h}$. Genes JP3 and JP5 increased its expression when plants were exposed to $4{ }^{\circ} \mathrm{C}$ for $8 \mathrm{~h}$ and $-1{ }^{\circ} \mathrm{C}$ for 4 h, but decreased its expression when the $4{ }^{\circ} \mathrm{C}$ treatment was extended for $16 \mathrm{~h}$. The heat shock treatment $\left(45^{\circ} \mathrm{C}\right)$ enhanced gene expression in plants that were not previously cold stressed; but in precold-stressed plants, gene expression was significantly reduced.
Many genes from different plant types have been reported to be induced by low temperatures (Gilmour et al., 2000; Kitashiba et al., 2004; Owens et al., 2002). From this research, 40 cold-inducible $P$. terminalis genes were identified. Northern blot analyses showed that seven genes had strong expression levels when they were exposed to $4{ }^{\circ} \mathrm{C}$ for $8 \mathrm{~h}$. However, the transcription levels decreased when the treatment duration was increased to $16 \mathrm{~h}$. In Arabidopsis, $D R E B$ transcription factors that regulate gene transcription are induced by a 40 min exposure at $4{ }^{\circ} \mathrm{C}$, reach the maximum level after $2 \mathrm{~h}$ and slowly decreased to a minimum after $24 \mathrm{~h}$ (Liu and Zu., 1998; Shinwari, et al., 1998). The induction of the transcription regulon in soybean, $S C O F 1$, was reported to begin its expression after $3 \mathrm{~h}$ at $4{ }^{\circ} \mathrm{C}$ and continue to increase for $72 \mathrm{~h}$ (Kim et al., 2001; Viswanathan and Zhu, 2002).

Although gene expression responses elicited by cold and heat share common features, cold and heat are two extreme stressors. In principle, cold should reduce the rate of enzymatic reactions, diffusions, and membrane transport, whereas heat would tend to increase them. In mammalian cells there are important differences in cellular responses to different stressors (Sonna et al., 2002). In this study, we found that both cold and heat-shock treatments can up-regulate gene transcription. However, when $P$. terminalis plants were exposed to 4 ${ }^{\circ} \mathrm{C}$ for $8 \mathrm{~h}$ before the heat-shock treatment, no gene expression was observed. Following a cold shock treatment, gene expression appears to be regulated to cope for the stressor while a heat shock treatment ends the process. Temperature changes from 4 to $45^{\circ} \mathrm{C}$ may also destroy some of the gene transcripts that accumulated during the $4{ }^{\circ} \mathrm{C}$ treatment.

\section{Literature Cited}

Gilmour, S.J., A.M. Sebolt, M.P. Salazar, J.D. Everard, and M.F. Thomashow. .2000. Over expression of the Arabidopsis CBF3 transcriptional activator mimics multiple biochemical changes associated with cold acclimation. Plant Physiol. 124:1854-1865

Kitashiba, H., T. Isshizaka, K. Isuzugawa, K. Nishimura, and T. Suzuki. 2004. Expression of a sweet cherry DREBI/CBF ortholog in Arabidopsis confers salt and freezing tolerance. J. Plant Physiol. 161:1171-1176.

Kim J.C., S.H. Lee, Y.H. Cheong, C.-M. Yoo, S.I. Lee, H. J. Chun, D.-J. Yun, J.C. Hong, S.Y. Lee, C.O. Lim, and M.J. Cho. 2001. A novel cold-inducible zinc finger protein from soybean,

Table 1. Cloned cDNAs identified through differential display search against NCBI (NT, EST) Database.

\begin{tabular}{|c|c|c|}
\hline Clone no. & Homologous genes & Identity $(\%)$ \\
\hline 1 & Tomato chlorophyll b-binding protein (Cab10b) gene & 86 \\
\hline 3 & Pisum sativum gda-1 gene & 85 \\
\hline 5 & Preinfection stage symbiosis-regulated cDNAs from Laccaria bicolor $\times$ P. resinosa L. bicolor & 97 \\
\hline 6 & SS pectin Sclerotinia sclerotiorum cDNA similar to $\mathrm{H}^{+}$-transporting ATP synthase beta chain & 95 \\
\hline 7 & Ice plant Lambda Uni-Zap XR expression library, $48 \mathrm{~h} \mathrm{NaCl}$ treatment Mesembryanthemum crystallinum cDNA clone & 85 \\
\hline 8 & Ribes nigrum mRNA for metallothionein-like protein, $86 \%$, RNI7577. & 86 \\
\hline 11 & Pennisetum glaucum seedlings exposed to cold $\left(4^{\circ} \mathrm{C}\right)$ stress cDNA clone & 91 \\
\hline 12 & Passiflora edulis PE-ACS1 mRNA for ACC synthase & 93 \\
\hline Others & Unidentified & \\
\hline
\end{tabular}




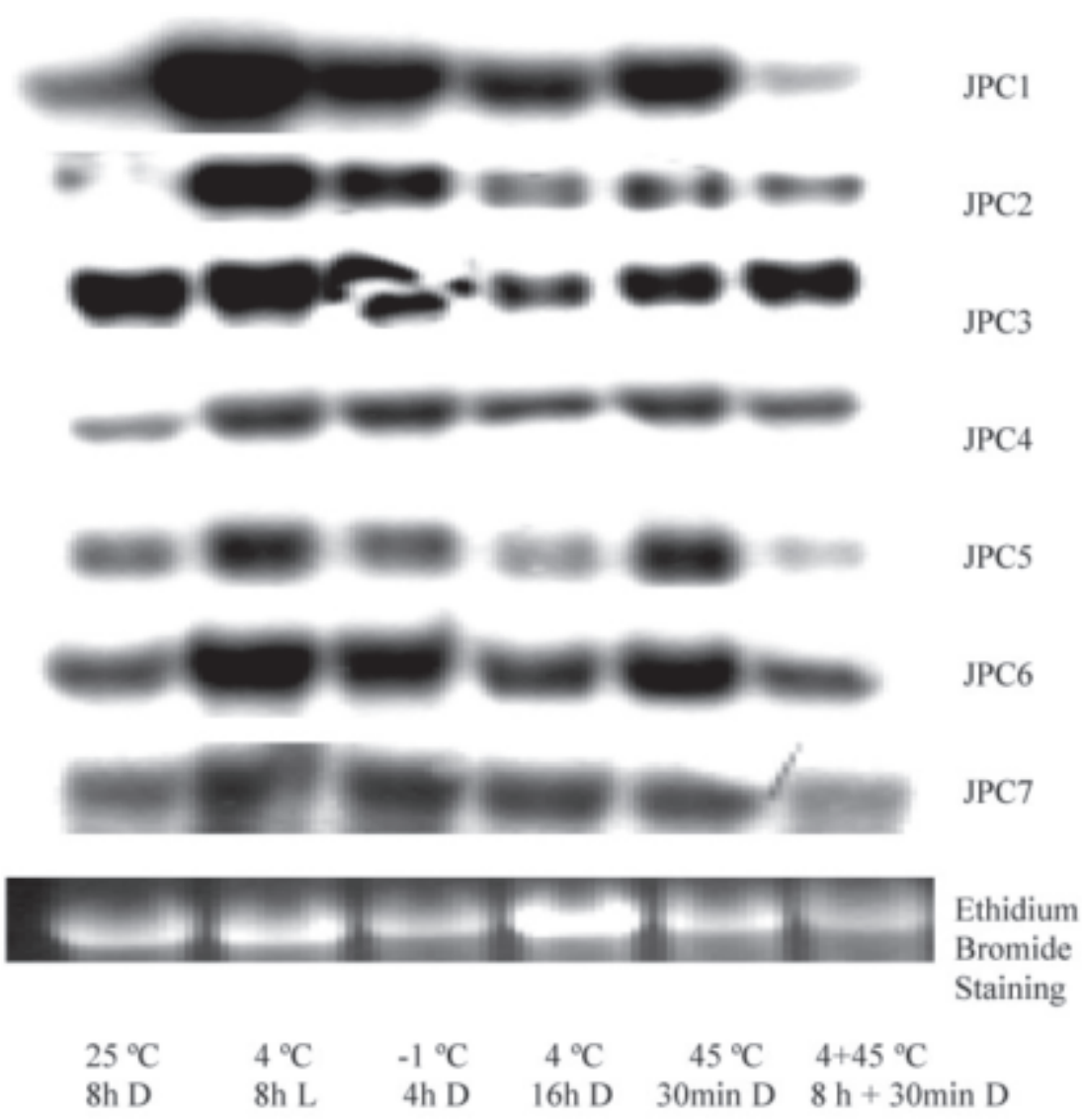

Fig. 3. Temperature-dependent accumulation of transcripts of cold inducible gene clones from Pachysandra terminalis. RNA samples were prepared from leaves that were incubated at $25,0,4,-1$, and $45{ }^{\circ} \mathrm{C}$ and analyzed by northern blot hybridization. The northern blot was hybridized with a cold-inducible gene clone. RNA loading was monitored by the ethidium bromide staining of the total RNA sample before transfer.
SCOF-1, enhances cold tolerance in transgenic plants. Plant J. 25:247-259.

Liu. J. and J.K. Zhu. 1998. A calcium sensor homolog required for plant salt tolerance. Science 280:1943-1945

Nishida, I. and N. Murata. 1996. Chilling sensitivity in plants and cyanobacteria: The crucial contribution of membrane lipids. Annu. Rev. Plant Physiol. Plant Mol. Biol. 47:541-568

Polisensky, D.H. and J. Braam. 1996. Cold-shock regulation of the Arabidopsis TCH genes and the effects of modulating intracellular calcium levels. Plant Physiol. 111:1271-1279.

Shinwari, Z.K., K. Nakashima, S. Miura, M. Kasuga, M. Seki, K. Yamaguchi-Shinozaki, and K. Shinozaki. 1998. An Arabidopsis gene family encoding DRE-CRT binding proteins involved in low temperature responsive gene expression. Biochem. Biophys. Res. Commun. 250:161-170.

Sonna, L.A., J. Fujita, S. Gaffin, and M.C. Lilly. 2002. Molecular biology of thermoregulation invited review: Effects of heat and cold stress on mammalian gene expression. J. Appl. Physiol. 92:1725-1742.

Tsonev, T., V. Violeta, G. Katya, P. Hyde, and J.H. Hamlyn. 2003. Low temperature enhances photosynthetic down-regulation in french bean (Phaseolus vulgaris L.) plants. Ann.of Bot. 91:343-352.

Viswanathan, C. and J.K. Zhu. 2002. Molecular genetic analysis of cold-regulated gene transcription. Philos. Trans. Royal Soc. London Biol. Sci. 357:877-886.

Zhou, S., R.J. Sauve, and M.T. Mmbaga. 2005. Adaptation of Pachysandra terminalis Sieb. \& Zucc. to freezing temperatures by the accumulation of mRNA and cold-induced proteins. HortScience 40:346-347.

Zhu, J.K. 2001. Cell signaling under salt, water and cold stresses. Current Opinion Plant Biol. 4:401-406. 